floods led to the creation of turbidity currents, in the sense of dense flows beneath bodies of relatively still and clear water, shallow or deep. We believe that the Old Red Sandstone " cyclothems " accumulated more slowly and more uniformly, probably in fluviatile and shallow lacustrine regimes where " normal " currents operated. Interestingly enough, the metamorphosed red sandstone-siltstone measures present in the Dartmouth Slates of SouthWest England, holding many sedimentary features in common with the Ditton Series, have appeared to certain workers to be a deep-water " flysch". There is now evidence that these beds are of continental, Old Red Sandstone facies (Dineley, in press).

Discovery of the features mentioned above demands no reversal of our beliefs concerning the deposition of the Old Red Sandstone, either of Britain or Spitsbergen. It does remind us, however, that the production of graded bedding, sole marks and deformational structures is not limited to environments where ill-sorted sediments are deposited rapidly by turbidity currents.
D. L. Dineley.
J. R. L. Allen.
Geology Department, UNIVERSITY, BRISTOL, 8.
Geology Department
UNIVERSITY, READING.

28th July, 1960.

\title{
WENLOCK STRATA OF SOUTH MAYO
}

SIR,- In his account of the stratigraphy and structure of the Wenlock strata of South Mayo (Geol. Mag., 1960, xcvii, 265), Professor J. G. C. Anderson describes two phases of folding affecting the Silurian strata of the Croagh Patrick syncline and assumes that the gently plunging folds which roughly parallel the axis of the major structures are the earliest folds in the area.

I have recently completed mapping the ground immediately to the south of the Owenwee river, and have found that a complicated tectonic sequence of events affects the southern limb of the syncline. The intense stretching of boulders in the basal Wenlock conglomerate is parallel to an $a$ direction lying on the axial plane of folds which plunge steeply to the west. These steep folds undoubtedly pre-date the first folds described by Professor Anderson, since the schistosity in the basal Wenlock psammites associated with the steep folds is, in places, deformed by a penetrative cleavage, dipping steeply northwards, which is axial to the first folds of Anderson. The steep cleavage which is prominent on the southern limb of the Croagh Patrick syncline can be shown to be a second structure on another line of evidence, since the folds with which it is associated face downwards, although the major structure faces upwards.

I am unable to agree with Professor Anderson's assertion that the major arcuate swings in strike of the southern limb of the syncline can be referred to a single phase of deformation associated with the north-westward plunging second folds. The major arcuate swing of strike around the northern margin of the Corvock granite is related to the intrusion of the granite stock and Stanton (1959) has shown that the swing in strike north-west of Cregganbaun is undoubtedly due to shearing parallel to the north-west to south-east dextral Maam faults.

\section{Department of Geology \\ THE UNIVERSITY, MANCHESTER. \\ 7th October, 1960.}

J. F. DeWeY.

\section{REFERENCE}

Stanton, W. I., 1959. The Lower Palaeozoic Rocks of South-West Murrisk, Ireland. Proc. geol. Soc. Lond. No. 1568, 67-73. 
SIR,-Minor structures in the basal Wenlock beds of Co. Mayo are extremely variable, particularly when it is studied as a whole; they include, among others, the steep westerly-plunging folds, mentioned by Mr. Dewey, especially in the matrix of the conglomerate. Moreover, the relation of boulder extension to structure is a controversial problem; the stretching of the boulders can also be interpreted as in $a$ " $b$ " direction parallel to the E.-W. folds including, in part of the S. limb, those plunging gently east.

There is a tendency to regard every different direction of minor structure as evidence of the existence of a separate fold-system irrespective of the nature of the formations and the geometry of their mapped boundaries, whereas minor structures, in different directions, even showing a local sequence, may develop within the one system. The complex structures in the highly inhomogeneous Wenlock conglomerate may well fall into this category; discussion of their possibly wider tectonic significance must await the publication of more detailed evidence than is possible in a letter.

No evidence whatever is afforded for the supposed tectonic effects of the granite. However, consideration of the position of the intrusion in relation to the symmetry of the arc it cuts does not support the view that it is the cause of the arcuate swing. Moreover, detailed mapping, both on its W. margin and on its complex N. margin, shows structures and stratigraphical boundaries striking straight at granite junctions.

Having ascribed the east arm of the Cregganbaun arc to this cause, $\mathrm{Mr}$. Dewey then invokes a second cause for the west arm. (Yet a third must be postulated for the arcing and N.W. folds remote from both granite and fault.) Dr. Stanton, it is true, attributes certain tectonic features in the Ordovician further S. to the Maam faults, but he has not "undoubtedly" shown that the swing in strike N.W. of Cregganbaun is due to these structures.

The Maam fractures are in fact part of a system of N.W. and N.E. tear faults which developed very late and may in fact be due to post-Carboniferous, N.-S. Armorican compression ; the arcs, on the other hand, are pre-Carboniferous. These faults are plentiful throughout a wide region and very commonly cut across formations with only very local drag or shear (as do the Maam Faults for part of their course). Where, however, a pre-existing grain approximately in the potential shear-direction exists, a fault will more readily and fully develop, as has happened in the case in question; this does not exclude the possibility of some shearing parallel to the fault-movement.
Department of Geology,
J. G. C. ANDERSON.

University College, CardifF.

18th October, 1960.

\section{DEPTH TO TOP OF POSTULATED WEARDALE GRANITE}

SIR,-Gravity surveys have revealed a region of negative Bouguer anomalies over the northernmost Pennines (the Alston Block) which is unrelated to the known geological structure and has been interpreted by Bott and MassonSmith (1957) as being caused by a buried granite (named the Weardale granite). At that time the top surface of the granite was estimated to be less than 5,000 feet deep. Since the publication of this paper certain advances have been made in the technique of depth estimation from gravity anomalies, and I should like to put on record an improved estimate before it is put to the test in a new borehole which is now being drilled at Rookhope, Co. Durham.

A method of depth estimation recently developed by Smith (1959) relies only on the measured second or third derivatives of the Bouguer anomalies and an assumed value for the density contrast. This method gives considerably " better" estimates than earlier methods (e.g. Bullard and Cooper, 1948; Bott and Smith, 1958) and has the added advantage that knowledge of the background gravity field is not needed. The estimates give maximum possible depths for the assumptions stated and refer to the top surface of the anomalous body and not to its centre of gravity or base. Therefore the estimate must be treated as a limit and not as the expected depth. 